\title{
HEALTH, POVERTY AND THE ELDERLY: CAN THE COURTS MAKE A DIFFERENCE?
}

\section{MARGARET A. SHONE*}

This article analyzes the relationship among health, poverty and the elderly and provides a basis for understanding the problems facing the aging population. The author suggests that the existing universal health care system in Canada has serious limitations in ameliorating these problems. She proposes that a combination of strategies such as improving the financial position of the elderly poor, reallocating health care resources from hospital to community care, and assisting elderly poor to exercise their rights could remedy shoricomings in our health care system. The courts can play a role in ameliorating the harsh effects of law and policy on elderly persons experiencing poverty and failing health. However, the author cautions that in the long run it is governments that must provide educational and remedial measures to address the root causes of these problems.
Le présent article analyse les liens existant entre la santé et la pauvreté chez les personnes âgées, et fournit un cadre permettant de saisir les problèmes auxquels doit faire face la population vieillissante. L'auteur suggère que le régime d'assurance-santé universelle en vigueur au Canada présente des limites sérieuses d cet égard. Elle propose une combinaison de stratégies destinées a corriger la situation: amélioration du statut économique des personnes âgées indigentes, réaffectation des ressources des hopitaux aux soins communautaires et assistance juridique. Les tribunaux peuvent jouer un rôle et contribuer à adoucir les rigueurs du droit et des politiques sur les personnes âgées qui vivent dans la pauvreté et dont la santé se détériore. Mais elle ajoute que, a long terme, ce sont les gouvernements qui devront fournir les mesures éducatives et correctives destinées à régler les causes premières de ces problèmes.

\section{TABLE OF CONTENTS}

I. INTRODUCTION $\ldots \ldots \ldots \ldots \ldots \ldots \ldots \ldots \ldots \ldots . \ldots . \ldots 839$

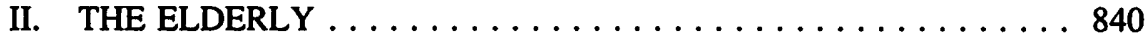

III. HEALTH OF THE ELDERLY $\ldots \ldots \ldots \ldots \ldots \ldots \ldots \ldots \ldots .842$

IV. POVERTY AMONG THE ELDERLY $\ldots \ldots \ldots \ldots \ldots \ldots \ldots 844$

V. EFFECT OF POVERTY ON THE HEALTH

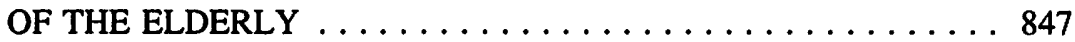

VI. LIMITATIONS OF THE HEALTH CARE SYSTEM IN MEETING THE NEEDS OF THE ELDERLY POOR . . . . 851

VII. SUMMARY OF THE RELATIONSHIP AMONG HEALTH, POVERTY AND THE ELDERLY $\ldots \ldots \ldots \ldots \ldots \ldots \ldots \ldots 53$

VIII. LAW, POLICY AND THE COURTS $\ldots \ldots \ldots \ldots \ldots \ldots \ldots \ldots 854$

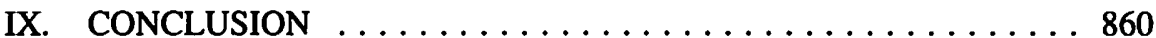

\section{INTRODUCTION}

At least two-fifths of elderly Canadians - more than 1,062,600 individuals - live in poverty or near poverty. For unattached elderly individuals, the rate is almost two-thirds; for the disabled elderly, four-fifths.

Counsel. Alberta Law Reform Institute, University of Alberta, Edmonton. This paper was prepared for the Canadian Institute for the Administration of Justice Conference on "Health Care, Ethics and the Law" held in Toronto, Ont., October 1990. 
The fact that the elderly experience poverty in such vast numbers is dismaying in and of itself. It is more dismaying when account is taken of the fact that low income is a correlate of poor health, and that evidence of this correlation exists in Canada notwithstanding universal health care insurance. It becomes extremely dismaying when the effects of poverty are added to the health problems that increase in both number and severity with increasing age for persons in all income brackets. In short, old age for Canadians is characterized typically by cumulating health problems accompanied by diminishing financial resources. Far too many elderly survive at bare subsistence level.

This is an especially troubling picture when one looks at the demographic predictions for the next $\mathbf{3 0}$ or $\mathbf{4 0}$ years. Over this time period the elderly in the Canadian population will increase in absolute numbers, expanding at an annual average rate of $3 \%$, compared with a rate barely above $1 \%$ for the entire population; ${ }^{1}$ they will constitute an increasingly higher proportion of the total population; and, among the elderly, the increases will be greater among persons in the older age groups (75 to 84 years and 85 and over) than for those aged 65 to 74 years. The older elderly are more likely than their younger contemporaries to have used up their private resources, and therefore to be dependent on the public purse for survival.

There is additional cause for despondency. Due to the combined effect of several factors, the elderly poor are likely to fall more deeply into poverty in the upcoming years. Those factors include the expected growth in the proportion of elderly in the population; the heavy federal debt load that is weighing on Canadian taxpayers; reductions in the federal share of funding for health care, education and social programs; the pressure on provinces to absorb more health care, social service and welfare costs for persons of all ages; and the GST encroachment into what has been traditionally a provincial tax base.

For persons who will join the elderly population over the next three or four decades, tracing a personal trajectory into the future will produce a clearer image of what lies ahead. ${ }^{2}$ The image will disturb women more greatly than men because, statistically, elderly women are more likely than elderly men to live in poverty. That is to say, the problems related to health, poverty and old age are largely women's problems.

\section{THE ELDERLY}

\section{A. DEFINITION OF ELDERLY}

It is the practice to define the "elderly" as persons with a chronological age of 65 years or over.

Age 65 is clearly an arbitrary cut-off. The fact is that aging is a process which takes place at different rates for different individuals. Many elderly continue to be healthy,

1. Leroy O. Stone and Susan Fletcher, The Seniors Boom: Dramatic Increases in Longevity and Prospects for Better Health (Ottawa: Minister of Supply and Services Canada, 1986), ch. 1.2.

2. Use of this technique was suggested by Dr. Robert Evans, speaking at the CIAJ Conference on Health Care, Ethics and the Law, Toronto, Ontario, October 10-13, 1990. 
active, and capable of leading productive, satisfying lives well beyond the threshold age of 65. As stated in a recent Canadian report, in health terms, there is no magical age at which one becomes a "senior":

... seniors are a heterogeneous group ... they are individuals dealing not simply with the generic problems of age, but with individual and specific health problems, life circumstances, and expectations. ${ }^{3}$

Given the differences in the aging process from one individual to another, and in the speed with which aging occurs, persons from 55 to 64 years of age - the "near elderly" - are also a significant group to consider with respect to the effect of poverty on the health and health care of elderly persons. The income and health care safety net for persons in the near elderly age group is less secure than the net for persons 65 years and over.

It should be noted, conversely, that with better health care, healthier lifestyles and advancements in medical knowledge and technology, the age cut-off used to define the elderly could well increase in future decades.

\section{B. DEMOGRAPHIC FACTS}

The elderly population of Canada today consists of about $2,650,000$ persons. This is slightly more than $10 \%$ of the total population of Canada, currently estimated at $26,440,000$ persons. $^{4}$

Canada, like other developed countries the world over, is an aging society. People are living longer, the fertility rate is dropping and, as a result, the relative proportion of older to younger persons is increasing - so much so that by the year 2025, the proportion of elderly is expected to double, from $10 \%$ to $20 \% .^{5}$ Due to the decline in mortality rates for older persons, the proportion of elderly in the advanced age groups - persons 75 to 84 years and over $85-$ is growing rapidly. This population may escalate at a rate of three or more times the rate for persons 65 to 74 years of age. In Canada, the population aged 75 and over is expected to grow from approximately 1 million to 3 million in the next 45 years and the group aged 85 and over to increase from 224,000 to nearly $750,000 .{ }^{6}$ Consequently, the condition of the elderly will command the increasing attention of society. To the extent that the elderly experience poor health and disability, the burden on society will be great. This fact has major implications for social programs and health care delivery.

There is a growing imbalance in the proportion of elderly women to elderly men. To begin with, Canadian women have a substantially greater life expectancy than Canadian

3. Health and Welfare Canada, The Active Health Report on Seniors - What We Think, What We Know, What We Do (Ottawa: Minister of National Health and Welfare, 1989) at 3, 9.

4. Alberta Statistical Review, First Quarter 1990 (Edmonton: Alberta Treasury Bureau of Statistics, 1990) at 1.

5. Supra, note 1.

6. Ibid. 
men: at the present time, the difference in life expectancy at birth is approximately seven years, 79.0 years for females and 71.9 years for males. ${ }^{7}$ To add to this, female life expectancy gains at the older ages have exceeded male life expectancy gains: in the past 50 years, from 1931 to $1980-82$, 65-year-old women have made a gain of 5.1 years in expected years of life remaining; 65-year-old men have made a gain of 1.6 years. ${ }^{8}$ The differences in life expectancy mean that the predominance of women increases at successively older ages. ${ }^{9}$ In Canada in 1986, for instance, for every 100 men aged 65 to 69 years there were 125 women the same age, while for every 100 men aged 80 to 84 years there were 175 women, and for every 100 men aged 90 years or more there were 267 women. $^{10}$

\section{HEALTH OF THE ELDERLY}

\section{A. DEFINITION OF HEALTH}

In the past, health care providers, politicians and the public approached health from a negative perspective. That is to say, they thought of health care in terms of

(1) pain, fever, or other symptoms of illness; (2) interference with the normal activities of life; (3) deviation from a predetermined norm; and (4) ability to respond to stress and physical insult."

In 1946, the World Health Organization (WHO) adopted a definition that approached health in a positive way. It defined "health" as a "state of complete physical, mental and social well-being and not merely an absence of disease or infirmity." ${ }^{12}$ The 1946 definition introduced the notion of general well-being into the concept of health, and moved the concept away from a focus on illness. Its adoption marked an important milestone in the health care field.

The WHO definition, and later applications of it in the United Nations, ${ }^{13}$ guides health policies being promoted in Canada today, as is apparent from two documents published recently by Health and Welfare Canada. The first document is Achieving Health for All:

7. Ellen M. Gee and Meredith M. Kimball, Women and Aging (Toronto and Vancouver: Butterworths Perspectives on Individual and Population Aging series, 1987) at 21.

8. Ibid. at 22 .

9. Mary Sue Devereaux, "Aging of the Canadian Population", Canadian Social Trends (Winter 1987) at 37.

10. Supra, note 1 , ch. 2.6.

11. Paul F. Basch, Textbook of International Health (New York and Oxford: Oxford University Press, 1990) at 29.

12. Preamble to the World Health Organization constitution adopted by the International Health Conference held in New York in 1946: WHO, The First Ten Years of the World Health Organization (1958) at 459. Canada ratified the WHO definition in the same year.

13. In 1977, the World Health Assembly set a target of "the attainment by all citizens of the world by the year 2000 of a level of health that will permit them to lead a socially and economically productive life," now commonly known as "Health for All by the Year 2000" or simply "HFA2000": supra, note 11 at 200. One outcome of HFA2000 was the adoption, in 1982, of the Vienna International Plan of Action on Aging (V.82-26767), aimed at guaranteeing social and economic security to older persons and affording them opportunities for citizen participation. 
A Framework for Health Promotion. ${ }^{14}$ This document portrays "health" as "a part of everyday living, an essential dimension of the quality of our lives," and as "a resource which gives people the ability to manage and even to change their surroundings."15 "Quality of life" is said to imply "the opportunity to make choices and to gain satisfaction from living."

The second document, a sequel to the first, is Mental Health for Canadians: Striking a Balance. ${ }^{16}$ It offers a "dynamic, interactive definition of mental health [that] reflects the inherently social nature of human experience, and the fact that individuals, groups and environments continually influence and are influenced by one another." The definition is:

Mental health is the capacity of the individual, the group and the environment to interact with one another in ways that promote subjective well-being, the optimal development and use of mental abilities (cognitive, affective and relational), the achievement of individual and collective goals consistent with justice and the attainment and preservation of conditions of fundamental equality. ${ }^{17}$

Because of this continual interaction, the definition "affirms certain values of society, namely those of human equality, justice, freedom of choice and social responsibility." The authors see the "equitable distribution and exercise of power" as being "clearly a crucial factor in mental health." The document emphasizes the importance for good mental health of adequate shelter and income, a setting that supports personal and spiritual growth, and opportunities with others for work, recreation and leisure - all areas in which the elderly poor experience problems.

The definition of "mental health" is useful in the context of this discussion because it moves beyond physical health to emphasize the importance to overall health of the components necessary to achieve mental and social, as well as physical, well-being - the three dimensions of health identified in the WHO definition.

\section{B. RELATIONSHIP TO DISABILITY}

The link between health and disability is also relevant. WHO defines a "disability" as "any restriction or lack of ability resulting from impairment to perform an activity in the manner, or within the range, considered normal."18 In short, a person has a disability if he or she has trouble functioning in the normal way. Poor health can be disabling, although the converse is not necessarily true; that is, it is possible to have a disability and yet to be healthy. Being unhealthy without being disabled to some degree is more difficult to imagine.

14. Jake Epp (Ottawa: Health and Welfare Canada, 1986).

is. Ibid. at 3.

16. Perrin Beatty (Ottawa: Health and Welfare Canada, 1988).

17. Ibid.

18. World Health Organization, International Classification of Impairments, Disabilities, and Handicaps (Geneva, 1980) at 143. "Disability" was defined as any limitation of normal activity in the Health and Limitations Survey (HALS) conducted by Statistics Canada in 1986 and 1987. 


\section{POVERTY AMONG THE ELDERLY}

\section{A. DEFINITION OF POVERTY}

Poverty is measured in relation to a "poverty line" which may be drawn using different approaches and assumptions. This is an important point because the poor according to one definition of poverty may be the near poor according to another, depending on the placement of the poverty line. That is to say, as in the case of the near elderly, a more complete picture can be seen by including information about the near poor.

Although it is placed a little lower than other poverty lines, the poverty line established by Statistics Canada is commonly used because the statistical data are readily available. Statistics Canada takes the approach of "determining an absolute measure of poverty by examining the essentials necessary for physical survival"; ${ }^{19}$ in other words, the line is "based on a subsistence conception of poverty." ${ }^{20}$ According to Statistics Canada, any individual or family that spends 58.5 percent or more of total income on the necessities of life - food, shelter and clothing - is considered poor. This is about $20 \%$ more than the proportion of annual income (38.5\%) that the average Canadian family spends on food, clothing and shelter. ${ }^{21}$ Statistics Canada varies its low income cut-offs according to the size of place of residence, with lower cut-offs for rural areas and higher cut-offs as the size of the place of residence increases.

\section{B. THE DOLLAR CUT-OFF}

In dollar terms, the Statistics Canada low income cut-offs for 1988 for individuals ranged from $\$ 8,559$ in rural areas to $\$ 11,574$ in cities having a population of 500,000 and over. For couples, the range was from $\$ 11,187$ to $\$ 15,270 .^{22}$ The median income for elderly persons in 1986 - the year of the most recent Canadian population census - was between $\$ 5,000$ and $\$ 9,999 . .^{23}$ The 1986 figures provide the baseline from which poverty in subsequent years is currently estimated.

\section{BREADTH OF POVERTY}

There are three measures of poverty in relation to the poverty line - the breadth of poverty, the depth of poverty and the duration of poverty.

19. David P. Ross and Richard Shillington, The Canadian Fact Book on Poverty 1989 (Ottawa: Canadian Council on Social Development, 1989) at 3-4.

20. $\quad$ Supra, note 7 at 53-54.

21. Peter Faid, "Older Women and Poverty: Fact or Fiction?" in Women and Aging Past, Present and Future (Edmonton: Seniors Advisory Council for Alberta, 1989) at 16.

22. National Council of Welfare, 1989 Poverty Lines (Ottawa: Minister of Supply and Services Canada, 1989) at 12.

23. Peter A. Dunn, Barriers Confronting Seniors with Disabilities in Canada, Special Topic Series from the Health and Activity Limitation Survey (Ottawa: Statistics Canada, 1990) at 28. 
As stated in the introduction, the breadth of poverty among the elderly is dismally high, 24.4\% over all households in $1986 .{ }^{24}$ The poverty picture worsens considerably when the rate of near poverty is included. An additional $15 \%$ of elderly couples and $21 \%$ of unattached elderly individuals had incomes that exceeded the line by only 20 percent or less. ${ }^{25}$ In sum, the breadth of poverty and near poverty among the elderly approaches a full two-fifths of all elderly. Poverty is distributed unevenly among the elderly, with unattached persons, disabled persons and women being at the greatest risk.

Unattached Elderly. The elderly poor are more likely to be unattached than to live in families. In 1987, nearly half $(47.9 \%)$ of unattached individuals in households headed by individuals 65 and over lived below the poverty line, compared with only $14.1 \%$ of individuals living in families. ${ }^{26}$ Altogether, approximately two-thirds of elderly unattached individuals lived in poverty or near poverty ( $47.9 \%$ plus $21 \%$ ). In contrast, elderly couples had a relatively low poverty rate, a mere $8 \% .^{27}$

Disabled Elderly. Poverty is more widespread among the disabled elderly than among the elderly generally. Disability results in a higher rate of poverty than does almost any other population characteristic. ${ }^{28}$ Statistics from the 1986 census reveal that approximately $60 \%$ of disabled persons aged 65 and over lived in poverty. ${ }^{29}$ Of these, $52.1 \%$ had an annual income between $\$ 5,000$ and $\$ 9,999 ; 8 \%$ had an income of under $\$ 5,000{ }^{30}$ Another $20.7 \%$ had an income ranging from $\$ 10,000$ to $\$ 14,999$. These persons fall into the poor or near poor category. Adding this percentage to the $60 \%$ living in poverty gives a total figure of over $80 \%$. In other words, four-fifths of all disabled elderly live in poverty or near poverty.

Elderly Women. Elderly women are at multiple risk of poverty. First, elderly women are more likely to be living in poverty than elderly men. Among families headed by a woman aged 65 or over, $16.8 \%$ live in poverty compared with $13.8 \%$ of families headed by a man of this age. The difference for unattached elderly persons is more dramatic. The $47.9 \%$ of unattached elderly individuals living below the poverty line include $52.1 \%$ of women compared with only $35.5 \%$ of men. Second, elderly women are more likely than elderly men to be unattached. Of all persons living in unattached households, according to the 1986 census, $34.2 \%$ - in absolute numbers, nearly one million - are elderly (65 years and over) and, of these, $61.6 \%$ are female. ${ }^{31}$ Third, a greater number and percentage of elderly women than elderly men are disabled, and therefore poor. Sixty per cent of women aged 65 and over - in absolute numbers, three quarters of a million - are disabled compared with $40 \%$ of men. ${ }^{32}$ This is partly because women live longer and disability increases with advancing age. To add to the insult, disabled elderly women

Supra, note 19 at 89 ; see also Table 7.2 at 68 .

Ibid.

Ibid. at 23.

Ibid. at 42.

Supra, note 23 at 28.

Ibid.

Supra, note 19 at 28 .

Ibid. at 42.

Supra, note 23 at 6. 
have lower incomes than disabled elderly men - approximately $72 \%$ of disabled elderly women report incomes under $\$ 10,000$ compared with just $45 \%$ of disabled elderly men. ${ }^{33}$ In consequence, unattached disabled elderly women have lower incomes than the elderly in any other category.

Overall the data again reveal that the relationship among health, poverty and the elderly is very much weighted as a women's issue. To sum up:

... it is important to remember that a number of social and economic issues affect how older women experience health problems. Women live longer than men, they are usually poorer than men, and because their husbands die earlier, they are more likely to live alone and, in extreme old age, to be institutionalized. ${ }^{34}$

\section{DEPTH OF POVERTY} line.

The depth of poverty measures the distance by which income falls below the poverty

The incomes of the elderly poor tend to bunch around the poverty line. In 1987, poor elderly couples reached $80 \%$ of the poverty line. ${ }^{35}$ In other words, poor elderly couples lived on an income $20 \%$ below the poverty line. The income of poor unattached elderly individuals reached $82 \%$ of (or fell $18 \%$ below) the poverty line. ${ }^{36}$ The dollar amount by which the average poor elderly household fell below the poverty line in 1986 was $\$ 2,476$ for an elderly couple and $\$ 1,839$ for an elderly individual. ${ }^{37}$

Poverty, as we have seen, is worse among the disabled elderly. In 1985, for example, $8 \%$ of disabled elderly persons had incomes below $\$ 5,000$. For a person living in a rural area, an income of $\$ 5,000$ would have reached approximately $60 \%$ of the poverty line (fallen $40 \%$ below the line); for a person living in a city, it would have reached only $45 \%$ (55\% below).

\section{E. DURATION OF POVERTY}

The effects of poverty are more debilitating when it is of longer duration, especially if there is no hope for the reversal of one's fortunes in the future. In the words of one author, "Poor persons lose not just the money but the security of income and their expectations for financial improvement. ${ }^{38}$ The Statistics Canada annual income survey does not yield data on duration. ${ }^{39}$

Ibid. at 28.

Supra, note 7 at 40.

National Council of Welfare, Women and Poverty Revisited (Ottawa: Minister of Supply and Services, 1990) at 10. The percentages are based on 1987 figures.

Ibid.

Supra, note 19 at 53.

Supra, note 21 at 16.

Supra, note 19 at 19. 


\section{F. SOURCES OF INCOME}

The poor elderly derive approximately 90 percent of their income from public programs: Old Age Security (OAS), the Guaranteed Income Supplement (GIS), Spouse's Allowance (SA), and provincial supplements. ${ }^{40}$ OAS payments are universal entitlements - although Bill C-69, passed by the House of Commons on June 12,1990, introduces a tax clawback for elderly persons whose income is $\$ 50,000$ or more - whereas the GIS and SA programs are income-tested and specifically designed to help the poor. ${ }^{42}$ The fact that fully one-half of all elderly persons qualify for the GIS underscores just how dire the income situation of the elderly is. ${ }^{43}$ Clearly, both the breadth and depth of poverty would be much worse were it not for these government-funded income security programs.

\section{EFFECT OF POVERTY ON THE HEALTH OF THE ELDERLY}

The National Council of Welfare reported recently that one of the "saddest facts of Canadian life is the health gap that separates rich and poor":

Simply put, well-off Canadians live longer and healthier lives than average or low-income Canadians. The reasons for the gap are not fully understood, but they appear to be due in large part to the debilitating conditions of life that poverty forces upon people. ${ }^{4+}$

In Achieving Health for All, "reducing inequities in the health of low- versus highincome groups" is one of three major health care challenges identified by Health and Welfare Canada. ${ }^{45}$ The report states that financially "disadvantaged groups have significantly lower life expectancy, poorer health and a higher prevalence of disability than the average Canadian". ${ }^{46}$ The elderly constitute a significant proportion of the poor in Canada; therefore, they are present among those who are affected adversely. The Canadian Council on Social Development has underscored the connection between poverty and poor health among the elderly by warning that "[w]ith the aging of our population, the burden on our health care system will be catastrophic unless we invest now in the health of our seniors. ${ }^{147}$

Supra, note 7 at 57, citing Sixty-Five and Older: A Report by the National Council of Welfare on the Incomes of the Aged (Ottawa: National Council of Welfare, 1984).

41. Bill C-69, An Act to Amend Certain Statutes to Enable Restraint of Government Expenditures, 2d Sess., 34th Parl., 1989-90.

42. Supra, note 19 at 75.

43. Supra, note 7 at 58.

44. National Council of Welfare, Health, Health Care and Medicare (Ottawa: Minister of Supply and Services, 1990) at 6.

45. Supra, note 14 at 4.

46. Ibid. at 2.

47. Canadian Council on Social Development, Canada's Social Programs Are in Trouble, published for the Campaign Against Bill C-69 (Ottawa: Canadian Council on Social Development, 1990) at 3. 


\section{A. LIFE AND HEALTH EXPECTANCY}

The elderly in all income groups are more prone to suffer health problems and disabilities than persons in younger age groups. ${ }^{48}$ The elderly poor suffer additional health hardship because persons living in poverty have both a lower life expectancy and a poorer health expectancy than persons living in higher income groups.

The association between poverty and mortality is well documented. The effects of poverty are more pronounced for men than for women, but they are present for both. One recent study related deaths to individual earnings over a period of years among men 65 and older who had contributed to the Canada Pension Plan. It found that:

The death rates for men between the ages of 65 and 70 declined steadily as the level of earnings in the years prior to retirement increased. The death rates at the lower end of the income scale were about twice as high as the rates at the upper end of the scale. ${ }^{49}$

A study conducted in 1986 compared the life and health expectancies of persons living in neighbourhoods of different wealth. ${ }^{50}$ Persons living in the richest neighbourhoods lived longer than persons living in the poorest neighbourhoods. The health gap in years of life for men was 5.7 years; for women, 1.8 years.

About $80 \%$ of those over age 65 report at least one health problem, compared to $54 \%$ of the Canadian population as a whole. (Supra, note 3 at 5.) Both the prevalence and severity of health problems and disability among the elderly increases with advancing age, and persons in older age groups are more likely to suffer multiple health problems.

The health problems suffered by older people also tend to be more chronic than those of younger people, and to increase in severity. (Ibid. at 3.) Forty-seven per cent, or nearly half the elderly population (65 years and over) have some form of disability, compared with $13 \%$ of the population across all age groups. (Supra, note 23 at 9 .) Mobility (73\%) and agility (61\%) disabilities are by far the most common, followed by hearing (43\%), seeing (24\%), and speaking (5\%). Mobility/agility disabilities in combination affect $81 \%$ of elderly persons with disabilities. Approximately $36 \%$ of disabled seniors have a disability with a mild level of severity, $37 \%$ a moderate level, and $27 \%$ a severe level. The rate of severity of disability increases dramatically with age: for example, the percentage of seniors with severe disabilities increases from $20 \%$ at age $65-74$ to $49 \%$ at age 85 or older. (Ibid. at 9-10.)

Overall, almost two-thirds of health problems reported by the elderly are reported by women. (Supra, note 3 at 6.) These health inequalities may be attributable to social and economic differences more than to gender-specific differences, or they may reflect the health problems of very advanced age. (lbid. at 17.) One telling piece of information is that elderly women who live alone use more drugs than other elderly persons. (Supra, note 7 at 41 , citing J. Porcino, Growing Older, Getting Better: A Handbook for Women in the Second Half of Life [Reading, Mass.: Addison-Wesley, 1983]). As has been seen, elderly women who live alone are extremely likely to be poor. Supra, note 44 at 9, citing Michael Wolfson et al., "Earnings and Death - Effects Over A Quarter Century," Research Paper Series No. 30, Analytical Studies Branch, Statistics Canada. The study was conducted by Statistics Canada and the Canadian Institute for Advanced Research. 
The association between poverty and poor health is also well documented. The studies show that "poor people bear a disproportionate amount of ill health and disability"." As stated in the report on the Canada Health Survey of 1978, "[i]t is clear that people of lower-income groups and with lower levels of education do not enjoy the same level of health as those Canadians of higher social and economic status." ${ }^{.52}$ Persons in the lowest income group live 11 years fewer than those in the highest income group, and they spend an average of 5.4 years in ill health, unable to do major activities, compared to 0.8 years for those in the highest income group. ${ }^{53}$

Even more dramatic is the disparity, between persons in the lowest and highest income groups, in the average number of years lived without health-related restrictions on their activities. For men the difference is 14.3 years -50 years for men in the lowest income group compared with 64.3 years for men in the highest income group. For women the gap is 7.6 years -59.9 compared with $67.5^{54}$

\section{B. SELF-RATED HEALTH}

Elderly persons living in poverty feel its effects on their health. The Active Health Report on Seniors found a very strong relationship between income and self-rated health, activity limitations, and happiness. On the subject of health, "those in the very poor category were five times as likely $(50 \%)$ to rate their health as only fair or poor as those in the upper-middle category (10\%)"..$^{55}$ Conversely, "those in the upper-middle income category were more than twice as likely (59\%) to rate their health as excellent as those in the very poor category (28\%)." As for activity limitations, $40 \%$ of persons aged 65 and over in the very poor group reported activity limitations, compared to $11 \%$ of the uppermiddle group. ${ }^{56}$ As for happiness, only $30 \%$ of the very poor, compared with $53 \%$ of the upper-middle group, reported that they were "very happy". Eleven percent of the very poor, compared with only $3 \%$ of the upper-middle group, reported that they were "not very happy". ${ }^{57}$ The results for stress were less clear-cut; nevertheless $45 \%$ of the very poor group, compared with just $27 \%$ of the upper-middle group, said that "life was very or fairly stressful". 58

\section{DISABILITY}

The need for help with the activities of daily living increases with age. For example, at age 65 to 74 , approximately $16 \%$ of disabled people require help making their own

\footnotetext{
si. Ibid. at 10.

52. Ibid. citing The Health of Canadians: Report of the Canada Health Survey (Ottawa: Statistics Canada and Health and Welfare Canada, 1981).

53. Ibid.

s4. Ibid. at 11.

35. Supra, note 3 at 18 . These statistics are for persons aged 55 to 64 , but the differences for persons 65 and over are similar.

36. Ibid.

57. Ibid. at 19.

58. Ibid.
} 
meals, at age 75 to $84,23 \%$ require help, and at age 85 and over, the need jumps to $46 \% .^{59}$ Poverty is a barrier to obtaining someone else's help with some or all of the activities of daily living. In the Health and Activity Limitation Survey, disabled elderly respondents cited cost, the need for someone else's help, or both as an impediment to physical exercise, affordable accommodation, special housing adaptations to assist in moving about, use of public transportation, leisure activities, and obtaining equipment aids.

\section{SELF-ESTEEM AND STATUS IN SOCIETY}

Poverty of income involves much more than the cruel uncertainties, pain and anguish of financial hardship. Persons living with persistently low incomes do not simply live "scaled down versions" of typical middle-class life; they are required to live "markedly different lives". ${ }^{60}$ In short, poverty invades every aspect of existence and forecloses choices that middle and upper income Canadians take for granted.

With poverty of income come poverty of spirit and poverty of power. ${ }^{61}$ By poverty of spirit is meant "the social and psychological damage that results when the struggle of daily existence seems almost too much to bear":

Poverty creates for many a crisis of identity. In a society ... where personal success is so strongly linked with self-esteem, poverty can destroy the individual's feelings of self worth and accomplishment. Stress and a sense of personal failure reinforced by negative stereotypes about the poor magnify the crisis. ${ }^{62}$

By poverty of power is meant the denial, automatically, of "full citizenship and freedom of choice." The following passage exemplifies the situation that faces poor elderly women:

A sad paradox for older women in poverty is that the poorer the woman, the more likely she is to be misunderstood, rejected and excluded by the many, yet at the same time she is increasingly dependent on the many: her neighbours, home care services, medical professionals. Her life becomes frighteningly dependent on the kindness, the good humour, the sense of justice and the morality of others. She becomes increasingly dependent on a society that is prepared to interfere in her daily life often without invitation or consent. Is it any wonder that with this state of fragile precariousness that poor older women feel excluded from becoming a contributing member of a community again? Thus the poverty of income leads to an ever more tragic poverty of spirit and a poverty of power. ${ }^{63}$

59. $\quad$ Supra, note 23 at 16.
60. $\quad$ Supra, note 21 at 29.
61.
$62 . \quad$ Ibid. at 16.
63.
Ibid.
Ibid. at 29.




\section{LIMITATIONS OF THE HEALTH CARE SYSTEM IN MEETING THE NEEDS OF THE ELDERLY POOR}

\section{A. DEFINITION OF HEALTH CARE}

The description "health care" refers to "an industry that provides a range of services and goods which may or may not be covered by government health care insurance plans". ${ }^{64}$ Health care is wider than "medicare", a word commonly used to refer "only to those medical and hospital services which are covered by provincial or territorial public health insurance plans". ${ }^{65}$

\section{B. LIMITATIONS OF UNIVERSAL HEALTH CARE}

One might think, at first blush, that with universal health care insurance, poverty would not make much difference to health care for the elderly. Not so. The elderly poor are adversely affected by various limitations in the universal health care plans and supplementary benefits that are available in the provinces and federal territories. Four such limitations will be mentioned. All are interrelated. They are that: (i) universal health care insurance does not cover all medical and medically-related costs; (ii) emphasis is placed on acute, rather than chronic, health problems; (iii) emphasis is placed on physical health, rather than on mental health and social well-being; and (iv) services are focused on hospital- rather than community-based health care. It is noteworthy that "enhancing people's ability to manage and cope with chronic conditions, disabilities and mental health problems" is the second of the three major health care challenges identified by Health and Welfare Canada in Achieving Health for All. ${ }^{66}$

Limited Benefits Coverage. Medicare coverage is fairly comprehensive for medicallyrequired services that are provided by medical, dental and other health care practitioners on an in-hospital or hospital outpatient basis, and for services provided by medical practitioners in the community ${ }^{67}$ However, the plans do not cover all medically-related and dental services. For example, the cost of out-of-hospital medications and routine dental care normally must be paid by individuals or from private insurance plans. ${ }^{68}$

Supplementary provincial plans provide additional coverage, but such coverage is restricted in terms of financial limits and time periods. In some cases, the coverage is lower than the actual cost of the goods or service, which may put the benefit beyond the reach of the elderly poor. In other cases, the patient must pay directly for the goods or service and then claim reimbursement from the insurer. Out-of-pocket payment in advance could prove an impossible burden for a person living on a subsistence income. In short, whereas persons who have middle and high incomes can make up the balance

\footnotetext{
64. Supra, note 44 at 1.

65. Ibid.

66. Supra, note 14 at 5 .

67. See the Canada Health Act, R.S.C. 1985, c. C-6.

68. Supra, note 44 at 1.
} 
in the cost of goods and services that are partially insured and purchase those that are not covered at all, persons living in poverty must do without or make some other sacrifice.

Acute, Not Chronic, Health Problems. The universal health care plans and broader health care system still tend to focus on the negative side of health, rather than the positive side. It has been claimed that medicare has "effectively 'locked in' established patterns of delivering health care," and that as a result "innovation in the delivery of health care services, as opposed to innovation in medicine, is far from commonplace in Canada." ${ }^{169}$ Funding for long-term care for the elderly and chronically ill "has a much smaller federal presence" and "is much less developed."70

Physical Health, Not Mental Health and Social Well-Being. Because of the focus on the negative side of health, physical health problems that threaten life and limb generally receive care but mental health and social well-being do not receive as much attention. The point is underscored by the fact that funding for "a hospital or institution primarily for the mentally disordered" is excluded from shared federal funding under both the Canada Health Act $^{71}$ and the Canada Assistance Plan. ${ }^{72}$

Hospital-, Not Community-, Based Health Care. As stated, the universal health care plans focus on in-hospital or hospital outpatient services, and on services provided by medical practitioners in the community. Many elderly persons want to stay in their own homes. In order to do so, they need "not only medical care but a variety of social supports to meet their non-medical needs" ${ }^{173}$ - care and support which the elderly poor cannot afford. Community-based home care could give the elderly poor the opportunity to continue to live at home and participate in the life of the family. Home care has the advantage of being less expensive than institutional care - compare $\$ 15,000$ per month for care in an acute care facility with $\$ 2,500$ per month to provide care for someone in the home $\mathrm{e}^{74}$ - although "in the short term, developing a new system will no doubt add to the cost." 75 Shifting the emphasis "from the current acute care model to one that provides better support in the community" would benefit elderly and chronically ill persons, among whom unattached elderly women living in poverty predominate. ${ }^{76}$ It is possible that "the shift would have occurred long ago if men were the ones who found themselves in nursing homes in old age. ${ }^{177}$

The expansion of home care does not mean that nursing homes and other long-term residential health care facilities will no longer be needed. The development of an adequate system of publicly insured, community-centred nursing home care is also vital

\footnotetext{
69. Ibid. at 38 .

70. Ibid. at 3.

7.. Supra, note 67, s. 2, defining "hospital".

72. R.S.C. 1985 , c. C-1, in which the definition of "home for special care" in s. 2 excludes hospitals.

73. Supra, note 44 at $63-64$

74. $\quad$ Christie Mjolness, "Home Care," The Spokesman (May 1990) at 2.

75. Supra, note 44 at 65.

76. Supra, note 7 at $50-51$.

77. Ibid. at 51, citing B.B. Hess, "Aging Policies and Old Women: The Hidden Agenda," in A.S. Rossi (ed.), Gender and the Life Course (New York: Aldine, 1985).
} 
to future health care for the elderly poor. ${ }^{78}$ The expansion of home care services might reduce the rate of institutionalization of the elderly. However, the need for nursing homes will grow as the proportion of elderly persons in the total population increases, and as the proportion of elderly persons in older age groups also increases - on average, the percentage of older disabled people residing in institutions almost doubles with every five years of age over 65; the percentage of people in institutions at age 65 to 69 is $4 \%$ compared with $43 \%$ at age 85 and older. ${ }^{79}$ (Canada has one of the highest rates of institutionalization of any western nation $-16 \%$ of the disabled elderly, or approximately $8 \%$ of all elderly persons, live in long-term care institutions. ${ }^{80}$ )

Improving the system of residential health care facilities would benefit elderly women substantially because more elderly women (approximately $19 \%$ ) than elderly men (11\%) live in institutions. ${ }^{81}$ Women over the age of 75 are twice as likely as men of the same age to be institutionalized in long-term care facilities. ${ }^{82}$ These figures are likely influenced by the longer life expectancy of women, ${ }^{83}$ and by the fact that elderly women are more likely to be unattached, live alone and lack family support. According to the 1986 census, of the $25 \%$ of elderly people who live alone, more than three-quarters $(77 \%)$ are women (34\% of all elderly women compared with just $14 \%$ of all elderly men). ${ }^{84}$ Living alone is a significant disadvantage because families provide far more services associated with activities of daily living to the elderly with disabilities than do agencies or neighbours. ${ }^{85}$ In short, "health care for the frail elderly woman is more likely to depend on the woman's own ability to obtain health care services - either services that are provided to her at home or services that are part of institutionalized care. ${ }^{186}$

\section{SUMMARY OF THE RELATIONSHIP AMONG HEALTH, POVERTY AND THE ELDERLY}

This would be a convenient stage at which to summarize what has been said about the relationship among health, poverty and the elderly, before proceeding to examine the implications for law, policy and the courts.

Health has been portrayed broadly. The concept of health endorsed embraces physical health, mental health and social well-being. Everyday living is an essential dimension of the concept. Important elements of everyday living include the ability to manage one's surroundings, the opportunity to make choices, and the accordance of social equality and justice.

Supra, note 44 at 68.

Supra, note 23 at 22.

Ibid. at 1 . The trend toward caring for the elderly in long-term care institutions has been increasing for the past two decades. William F. Forbes and Jennifer A. Jackson, Institutionalization of the Elderly in Canada (Butterworths, Toronto and Vancouver, 1987) at vii.

Ibid.

Supra, note 7 at 51.

Supra, note 3 at 7.

"1986 Census Highlights: Changes in Living Arrangements" (1989) 12 Can. Soc. Trends 27 at 28. Supra, note 23 at 17.

Supra, note 7 at 40 . 
Poverty has been shown to be extremely widespread among the elderly. Unattached persons, disabled persons and women are at the greatest risk of poverty.

At the micro, or individual, level poverty has an adverse effect on health. The elderly poor have lower life spans and endure disability for longer periods of time than persons with higher incomes. Poverty of income is accompanied by poverty of spirit which takes the form of reduced self-esteem, and by poverty of power which stems from a low status in society and an inability through lack of means and opportunity to participate equally with others.

At the macro, or system, level issues arise about fairness to the elderly poor in the allocation of economic and health care resources. At present, the health care system leans in the direction of short-term hospital-based medical care for physical health problems rather than long-term community-based care that will promote the physical and mental health and social well-being of elderly persons suffering from chronic illness.

\section{LAW, POLICY AND THE COURTS}

\section{A. COURTS HAVE A ROLE TO PLAY}

It is evident that health problems, poverty and old age combine to produce an enormously disadvantaged group, one that is elderly - in a society that celebrates youth; poor - in a society that confers status on those with monetary wealth; sick and disabled - in a society that admires intellectual and physical strength, prowess and energy; and largely female - in a society in which men hold the predominant power and are the political decision-makers.

Clearly, the courts alone cannot remedy all of these disadvantages. A great deal of the responsibility for solutions falls on the shoulders of the legislators, and on economists, health care providers and other experts. Nevertheless, the courts have an important role to play at both the micro and macro levels. The role shows itself most visibly in the courts as the holders of the supreme constitutional power granted under the Canadian Charter of Rights and Freedoms, and as the institution responsible to protect individuals against the infringement of federal, provincial and territorial human rights legislation. Under the Charter, the courts must be vigilant to ensure that the elderly poor are granted the protection of life, liberty and security of the person conferred by section 7 and the protection of the equality rights conferred by section 15 . The protection against adverse discrimination in respect of three categories named in section 15 of the Charter - age, sex, and mental or physical disability - is particularly relevant where the health of elderly persons is put at risk by poverty. Because the Supreme Court of Canada has held that the categories of discrimination are not closed, ${ }^{87}$ it might be found that the Charter also protects against discrimination on the basis of wealth. 
The purposive approach to equality rights, established by the Supreme Court of Canada in the Andrews case, ${ }^{88}$ holds the potential to protect persons in disadvantaged groups from the systemically adverse discriminatory impact of laws that may or may not be objectionable on their face. ${ }^{89}$ It also holds the potential to protect vulnerable individuals from unintended adverse discriminatory effects. ${ }^{90}$ Given the disadvantages faced by unattached elderly individuals, the disabled elderly, and elderly women in the spheres of both income and health care, the courts might find reason to apply principles relating to systemic discrimination, or to unintended discriminatory results in individual cases. Because the Charter gives them latitude to fashion suitable remedies, the courts may choose to extend benefits to persons or groups who are adversely discriminated against by their exclusion from a class of persons who are eligible to receive income security, health care or related benefits under public programs. ${ }^{91}$ The courts may approve affirmative action to improve the situation of elderly women whose income needs are generally greater than those of elderly men, and whose health needs are different to a significant extent.

\section{B. THREE STRATEGIES FOR CHANGE}

Three strategies which would contribute to diminish the adverse effects of poverty on the health of the elderly will be discussed. They are: (i) improving the financial position of the elderly poor, (ii) reallocating health care resources to benefit the elderly poor; and (iii) assisting the elderly poor to exercise their rights. A fourth area, augmenting health care resources, is not discussed because of the reality that those resources are more likely to shrink than enlarge in future years. Each of these strategies involves the interaction, to a greater or lesser degree, of law, policy and the courts. With respect to each of them, the rights and freedoms guaranteed to individuals in the Charter are important.

\section{Improve the Financial Position of the Elderly Poor}

One obvious way to ameliorate the adverse effects of poverty on the health of the elderly would be to provide more income. With higher incomes, the elderly poor would be able to pay for more of what they need, be it better nutrition; more satisfactory accommodation; special housing adaptations; house and yard maintenance; leisure, exercise and recreational activities; health care appliances or other aids; or anything else. Anxiety would be reduced (for example, about the ability to meet unforeseen future

88. Ibid.

89. E.g. Brooks v. Canada Safeway Ltd. [1989] S.C.C. D. 1831-02; Janzen v. Pharos Restaurant (1989) 95 N.R. 81, also cited as Janzen v. Plary Enterprises Ltd. [1989] S.C.C. D. 1831-03; and Lavallee v. $R$. [1990] 4 W.W.R. 1 , 55 C.C.C. (3d) 97.

90.

Central Alberta Diary Pool v. Alberta (Human Rights Commission) [1990] 6 W.W.R. 193, 72 D.L.R. (4th) 417 (S.C.C.).

9. E.g. Schachter v. Canada (1990) 66 D.L.R. (4th) 635 (F.C.A.), leave to appeal to the S.C.C. granted November 15,1990 , File 21889 . The extension remedy is currently being sought for poor women aged 60 to 64 who do not qualify for the means-tested spouse's allowance because they are divorced or never married. 
circumstances). Choices would present themselves, thereby promoting individual autonomy and helping to heal the poverty of spirit that follows poverty of income.

Of the several examples that could be given of ways the financial position of the elderly could be improved, four follow. The first three have to do with employment; the fourth, with family obligations. Two measures that are not mentioned, mainly because they have more to do with the legislators than with the courts, are raising the level of income provided by income security programs and reforming pension legislation.

Protect against age discrimination in employment. Protecting the elderly from discrimination in employment would assist them to remain financially independent by staying in the workforce and receiving workplace benefits. ${ }^{92}$ It would also help to relieve the burden of supporting the increasing proportion of elderly persons in the population that will fall on the shoulders of a decreasing proportion of younger persons over the next few decades. As science advances and good health is preserved by persons of increasingly older ages, the pressure to open up the work force is certain to grow.

Lift mandatory retirement requirements. Clearly, lifting mandatory retirement requirements would assist elderly persons who wish to do so, and are qualified, to stay in the work force. In this regard, the approach taken by the dissenting justices in the batch of judgments on mandatory retirement issued by the Supreme Court of Canada on December 6, 1990 would do more to promote the health of the elderly in general and the elderly poor in particular than the approach taken by the majority who found mandatory retirement to be reasonably justified. ${ }^{93}$ Surely the dissenting justices have anticipated the law of the future.

Ensure gender equality in the workplace. This measure would help to improve the income-earning potential of women during their working years and to reduce the economic dependence, in old age, of women on men and the public purse. Here, the implementation of policies such as pay equity, equal pay for work of equal value, flexible work arrangements, and desegregation of the workplace, where women are concentrated in the low-paid sectors, ${ }^{94}$ would assist women to accumulate wealth during their productive years and to look after themselves in old age.

Enforce filial obligations of support. The enforcement of filial obligations of support is not a measure to be favoured. Nevertheless, although it is seldom enforced, legislation imposing a duty on children or other family members to maintain their parents or elderly

E.g. Tetreault-Gadoury v. Canada (Employment and Immigration Commission) (1988), 53 D.L.R. (4th) 384 (F.C.A.), leave granted to state constitutional questions and to extend time [1989] 2 S.C.R. 1110, appeal heard January 30, 1991 and judgment reserved; and Saskatchewan (Human Rights Comm.) v. Saskatoon (City of [1990] 5 W.W.R. 577, 72 D.L.R. (4th) 127 (Sask. C.A.). 
relatives does exist on the statute books of nine provinces. ${ }^{95}$ The reason for its disuse may relate to harsh criticisms that have been levelled at the economic and social ramifications of such legislation, for example: (i) the financial dependency of a parent upon the child causes tension and stress; (ii) children have competing support obligations to their spouses and offspring; and (iii) forcing adult children to include parents as part of their financial obligations may have the effect of perpetuating poverty. ${ }^{96}$ In difficult economic times, governments may look to these laws as "a method of relieving a burden that would otherwise be cast on the public at large", as is currently happening in the United States. ${ }^{97}$

\section{Reallocate Health Care Resources}

A second way to ameliorate the adverse effects of poverty on health would be to reallocate health care resources in a manner that is more equitable to the elderly poor. This would be a challenging task. It would involve making difficult comparisons about the nature of the health problems experienced by persons in different groups comparisons between elderly persons and persons in younger age groups; between elderly men and elderly women; and between one sort of health problem and another. What, for example, are the relative merits of health care aimed at saving the lives of persons aged 40 to 59 at high risk of death from heart disease compared with health care aimed at relieving or curing Alzheimer's disease, depression or osteoporosis? What are the relative merits of supporting research into one or another of these illnesses? (The risk of heart disease affects predominantly men; the other three diseases are suffered predominantly by older women.) Does the exception from the Canada Health $A c t^{8}$ and the Canada Assistance Plan ${ }^{99}$ of federal funding for hospitals or institutions that exist primarily to provide health care for persons with mental illness discriminate unreasonably against such persons, given that federal funding is available for hospitals or institutions providing care for persons with illnesses of every other sort? (Mental illness is experienced by a high percentage of elderly persons, especially elderly women in advanced age groups.) From the perspective of the individual, is placement in a facility funded at one level unreasonable discrimination when persons in a similar condition are placed in a facility funded at a higher level? ${ }^{100}$ It is critical continually to ask questions and to seek answers that will produce equity and fairness to individuals and meet the needs of the larger society.

Freda Steele, "Financial Obligations Toward the Elderly: Filial Responsibility Laws", in Margaret E. Hughes and E. Diane Pask (eds.) National Themes in Family Law, Selected Papers Presented at the 1987 Canadian Association of Law Teachers Family Law Conference (Carswell, 1988) 99, at 106. Ibid. at 112.

Supra, note 95 at 99.

Supra, note 67.

Supra, note 72.

The Ontario High Court said "No" in Ontario Nursing Home Assn. v. Ontario (1990), 72 D.L.R. (4th) 166, appeal 580/90 filed with the Ont. C.A. on August 14, 1990. It also held that section 7 of the Charter was not violated because there was no evidence that the patient was not being adequately cared for. 
Bearing the foregoing discussion in mind, three directions for the reallocation of health care resources that would benefit the elderly poor will be discussed. They are: (i) shifting the focus of health care delivery from hospitals to the community; (ii) targeting the elderly poor for preventive health care education; and (iii) setting minimal standards of institutional care.

Shift the Focus from Hospital to Community Care. Improved community care, and greater integration of the medical and non-medical aspects of care, would assist the elderly poor with health problems to meet the exigencies of daily life in the community and thereby avoid or postpone an institutional placement. In particular, such measures would benefit poor disabled unattached elderly women. Improved community care and support would also help to maximize the choices available to individuals, and choice is healthenhancing.

Target the Elderly Poor for Preventive Health Care Education. A very strong correlation exists among income, education and health. ${ }^{101}$ It can reasonably be concluded, therefore, that at least some of the health differences experienced by persons in the lower income groups are related more to their lower educational backgrounds than to their age. ${ }^{102}$ The Active Health Survey found that the elderly were more likely than persons in younger age groups to use sleeping pills and tranquillizers, and less likely to own a first aid kit or a smoke detector, to have had recent first aid training, and to have knowledge of cardio-pulmonary resuscitation (CPR). ${ }^{103}$ Targeting the elderly poor for preventive health care education could help to bridge the gap between the health care practices of persons in older and younger age groups in these areas.

The diagnostic practices employed by elderly women would make another worthwhile target. Women 65 and older are less likely than younger women to know about and have adopted diagnostic practices relating to breast examination. They are only half as likely to have undergone a Pap test in the past year (32\% compared with $63 \%$ of women under age 55). ${ }^{104}$ That this situation is unsatisfactory can be underscored by contrasting the fact that nearly nine out of ten adults 65 and older adopt the diagnostic practice of having an annual blood pressure check.

Set Minimum Standards of Institutional Care. The protection of life, liberty and security of the person in section 7 of the Charter provides a basis for insistence upon adequate care for disabled persons living in institutions. Where the care is inadequate the courts could consider using their judicial powers to specify the minimum standards that ought to be met. Take the striking fact that $56 \%$ of the disabled elderly living in institutions report needing some housing adaptation $-37.3 \%$ citing elevators, and $37.3 \%$ citing street level entrances. (It will be recalled that poor disabled elderly women

\footnotetext{
10t. Supra, note 3 at 20 , reporting the existence of a very strong relationship between education and selfrated health, activity limitation, and happiness.

102. Ibid.

103. Ibid. at 10.

104. Ibid. at 15.
} 
comprise a high percentage of this group.) Is adequate care being provided where independent mobility is restricted in this way?

\section{Assist the Elderly Poor to Exercise Rights}

A third strategy for ameliorating the adverse effects of poverty on the health of the elderly poor involves empowering them to assert their rights, and thereby to combat the poverty of spirit and the poverty of power that accompany the poverty of income. The measures that could be taken include educating the elderly poor about their rights and assisting them to exercise and enforce those rights.

Educate About Rights. The existence of a "very strong correlation" between income and education has been noted. The linkage suggests that the elderly poor may not have sufficient knowledge of their rights. A further complication is that the law relating to health care, income support and other matters is continually changing. In the area of health care, the shift from physician to patient decision-making may not be known or understood by persons who grew old in a different health care era and are not used to being entrusted with their own decisions. (As lawyers and judges know, the requirement of patient consent in health care matters was not firmly established in Canada until 1980, when the Supreme Court of Canada delivered its judgment in the case of Reibl v. Hughes. ${ }^{105}$ ) Enduring powers of attorney over health care, elderly abuse legislation, and modern guardianship laws that promote the autonomy of the person who is under guardianship are just beginning to be introduced. Better education about rights is likely to reveal choices and thereby enhance health. It could foster self-determination and autonomous decision-making. It also might help the ability to resist coercion. The elderly poor with health problems tend to be emotionally dispirited, as well as physically, socially and financially dependent on others. For these reasons, their wishes and decisions are more readily overborne than those of healthy, confident, independent persons.

Assist To Exercise and Enforce Rights. Knowledge of rights is not always enough. The poverty of spirit that accompanies poverty of income crushes confidence. Therefore the elderly poor are likely to be hesitant to request assistance, and reluctant to assert rights. Because of past social roles, elderly women may not be accustomed to expressing their wishes and making decisions. In consequence, at times the elderly poor will need assistance in exercising and enforcing rights. The help provided might take the form of personal advocacy to claim individual rights, help organizing the elderly poor for political action to seek rights, or publicly funded legal assistance. It might involve the relaxation of legal costs and requirements that block access to justice - for example, a court could refuse to order an elderly person living in poverty to post security for costs. ${ }^{106}$

\footnotetext{
105. [1980] 2 S.C.R. 880, 114 D.L.R. (3d) 1.

106. E.g. Shackelly v. Adelphi Holdings [1988] B.C.D. Civ. 212-02 (B.C.C.A. in Chambers).
} 


\section{CONCLUSION}

Many factors affect the relationship among health, poverty and the elderly, which means that the adverse effects of poverty on the health of the elderly cannot be wholly alleviated by adopting any single measure. They cannot be remedied exclusively by applying the protections afforded by the legal system, or by changing economic policies, or by reallocating public dollars, or by restructuring the health care system, or by introducing new social programs. No single system, in and of itself, can provide a complete response. What is needed is a concerted effort by all of the players in the total complex of medical, legal, social, economic, political and other systems in which the problem exists.

The courts, within the limits of their powers, have opportunities to render judgments that will ameliorate the harsh effects of law and policy on elderly persons who are the unfortunate victims of low income and ill health. The courts can make a difference. However, a caution is in order concerning the use of law and the Charter to realize social policy objectives:

\footnotetext{
While there is considerable public support for using legal measures to curb modem social problems, it is not clear that these measures work in the long run. Social reformers are increasingly concerned that governments tend to over-emphasize the legalistic "social control" approach to dealing with complex social matters, at the expense of providing educational and remedial measures to address the root causes of these problems. ${ }^{107}$
}

To conclude, understanding the role of the courts means analyzing the intersection of the many factors that affect the relationship among health, poverty and the elderly "to see how that law and practice is being continually constituted."103 The use of law and the courts to ameliorate the adverse effects "should be understood as an ongoing process of implementation". ${ }^{109}$ 14 no. 2 (Spring 1990) 30 at 33.

108. Steve Bottomley, "Mental Health Law Reform and Psychiatric Deinstitutionalization: The Issues in New South Wales" (1987) 10 Int'l J. of Law and Psychiatry 369 at 373. 